\title{
The relationship between sustainable innovation and product or service innovation: a survey in companies in Rio Grande do Sul
}

Eliana Andréa Severo

Department of Professional Master in Business Management, University Center UniFBV, Recife, Brazil

Marcia Marisa Santanna Perin

Department of Business Administration, Faculdade Meridional, Passo Fundo, Brazil

Julio Cesar Ferro De Guimarães

Department of Business Administration, Federal University of Pernambuco, Recife, Brazil, and

Elaine Taufer

\section{Department of Business Administration, Faculdade Meridional,} Passo Fundo, Brazil

\begin{abstract}
Purpose - Environmental problems and natural resources scarcity are changing contemporary organizations management. The current society quest sustainable companies, mostly concern with the consumption and efficient management of natural resources; those innovative and sustainable companies have the capacity to create innovations and beneficial outcomes for the environment and society. The purpose of this paper is to analyze the relevance of sustainable innovation on products and services innovation, in companies in the northern region of Rio Grande do Sul (Brazil).

Design/methodology/approach - In the research, the authors applied a descriptive and quantitative method, through exploratory factor analysis (EFA), with the use of varimax rotation and multiple linear regression. The final sample of the survey consists of 107 respondents.

Findings - The results indicate that sustainable innovation (SI) has an influence on products and services innovations in the organizations, moreover the process innovations can provide reduced energy consumption and waste emissions, indicating the awareness regarding the environmental issues.

Research limitations/implications - It is emphasized that environmental issues must be linked to investments in environmental education projects in organizations, thus enabling a systemic and effective vision on this issue.

Practical implications - This research presents managerial and academic contributions, as it has developed a scale to measure the importance of SI on products and services innovation.

Originality/value - The study developed a measurement model, with observable variables based on the specialized literature. The measurement model consists of the constructs of product/service innovation and SI, which were statistically validated through the tests of normality, reliability and EFA.
\end{abstract}

Keywords Innovation, Sustainable innovation, Sustainable company, Rio Grande do Sul

Paper type Research paper

C Eliana Andréa Severo, Marcia Marisa Santanna Perin, Julio Cesar Ferro De Guimarães and Elaine Taufer. Published in Revista de Gestão. Published by Emerald Publishing Limited. This article is published under the Creative Commons Attribution (CC BY 4.0) licence. Anyone may reproduce, distribute, translate and create derivative works of this article (for both commercial and non-commercial purposes), subject to full attribution to the original publication and authors. The full terms of this licence

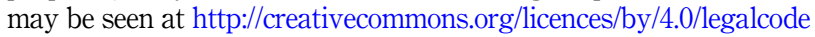


REGE

27,4

320

\section{Introduction}

Innovation is regarded as a prime source for companies to remain in the market, enabling competitive advantage, economic development and changes in society. Companies maintain competitive advantage not just with a single innovation, but by a concatenation of innovations over time (Schumpeter, 1934; Calantone, Garcia \& Dröge, 2003). In this context, it is relevant to categorize the dimensions of innovation, as product or process as it has relation with the strategy that a company adopts to meet the demand and market opportunities, capitalizing on the capacity and organizational competence. The system integration, extensive networks, flexible and personalized response also the continuous innovation will enable greater financial performance, which in turn will be more extensive if the products or the input processes are adopted early and quickly and if there is interrelationship between the two of them (Gopalakrishnan, 2000; Tidd, 2006; Xin, Yeung, \& Cheng, 2010; Prajogo, 2016).

Long-term investments, the development of processes and organizational skills are needed to translate scientific and technological opportunities in new successful products and services, which are widely adopted and supported, an equal and sometimes greater, emphasis is needed concerning the outputs of the process innovation, more specifically the diffusion and adoption of process innovation (Tidd, 2006). Furthermore, innovation must be seen not only as a competitive advantage conquest strategy but also as a maintaining strategy (Tidd, 2001).

In this scenario, innovation is a significant driver of different types of organizational performance (Vincent, Bharadwaj \& Challagalla, 2004). Although the idea of innovation is directly linked to technology, the concept can have different meanings based on contextual variables and understanding these innovation factors is critical to the development and dissemination of future technologies (Baskaran \& Mehta, 2016). To address this issue, the dissemination of technological and organizational innovation might be oriented to improve people's quality of life, in addition to developing strategic and economically viable innovations, innovation can currently be seen as a latent need to undertake environmental and social issues and contemplate current and future needs (De Medeiros, Ribeiro \& Cortimiglia, 2014; Franceschini, Faria \& Jurowetzki, 2016). According to Hansen, GrosseDunker and Reichwald (2009), corporations increasingly subscribe to the principles of corporate sustainability, which is generally described as the integration of economic, environmental and social dimensions.

Systems integration and extensive networks, flexible and personalized response and continuous innovation will enable greater financial performance, which in turn, will be more extensive if the products or processes are introduced early and adopted quickly (Gopalakrishnan, 2000). In line with this, it is necessary for companies to develop a holistic understanding of innovation and their importance and impact on environmental sustainability, a suitable environmental management can also provide a competitive opportunity impacting the community (González-Benito \& González-Benito, 2006; Van Den Heiligenberg, Heimeriks, Hekkert \& Van Oort, 2017).

There is a noticeable increase in society environmental awareness; however, there are still significant changes to be done so that businesses can be more environmentally efficient, aiming at cleaner production and efficiency of resources that end up reflecting on generating income and benefits for business and society (Khalili \& Duecker, 2013; Luken, Van Berkel, Leuenberger, \& Schwager, 2016; Bolis, Morioka, \& Sznelwar, 2017). Environmental sustainability is positively related to the reduction of inputs used in production, increased reuse and recycling, as well as increased productivity and, consequently, increased competitiveness and improved organizational performance; while improving environmental and financial performance (Paulraj, 2011; Dowell \& Muthulingam, 2017; Severo, Dorion \& Guimarães, 2017a; Liu, Zhu \& Seuring, 2017). 
To explore this issue, the research question is translated as: what is the importance of sustainable innovation in product innovation and services? Coherently, this study aims to examine the importance of sustainable innovation on products and services innovation, in companies in the northern region of Rio Grande do Sul state (Brazil). In addition to this introduction, the article presents the theoretical inherent in innovation and sustainable innovation; methodology; results and discussions and conclusions.

\section{Conceptual framework \\ 2.1 Innovation}

Innovation is seen as a prime source for companies to remain in the market, enabling competitive advantage, economic development and many changes in the society; thus constituting a process involving situations and determinations of new developments, as well as the inclusion of derived knowledge tools, artifacts and mechanisms by which people are integrated into the environment (Schumpeter, 1934; Garcia \& Calantone, 2002; Calantone, Garcia \& Dröge, 2003). In this context, Schumpeter (1934) introduced the concept of creative destruction by which innovation cycles shape economic and competitive landscapes, providing an explanation of why some firms outperform others; its definition of innovation is characterized as new combinations covering five cases: the introduction of a new good or a new quality; the introduction of a new production method; the opening of a new market; the conquest of a new source of supply of raw materials and the realization of the new organization of any industry, like the creation or the breaking of a monopoly position.

With the company restructuration intangible assets can be considered those hardly imitated or replaced by competitors, among them the innovative capacity of a company, they have been identified as the source of competitive advantage of successful companies (Brito, Brito \& Morganti, 2009). Thus, the role of innovation can be seen as essential in the pursuit of higher corporate performance and as an organizational activity that is inherently beneficial (Gopalakrishnan, 2000; Dosi, 1990). Companies maintain competitive advantages not just by a single innovation, but by a concatenation of innovations over time, and it must be perceived as a process that involves initial failures, recycling between stages, dead ends and jumps out of sequence, demonstrating that it should not be considered as a linear model (Calantone, Garcia \& Dröge, 2003; Tidd, 2006).

Innovation can occur in two basic forms: (1) product innovation, which are basically changes in the products or services offered by an organization, such as the development or use of new components, features and technologies to produce new products and (2) innovation processes, which can be considered as changes in the ways products and services are created and delivered, as well as the improvement of production processes technologies necessary to produce a certain product (Tidd, 2001; Prajogo, 2016; De Guimarães, Severo, Dorion, Coallier \& Olea, 2016). In this context, innovation can then be a new product or service, a new structure or administrative system, a new technological process in production, a new plan or a program related to the members of the organization (Damanpour, 1991). According to the Oslo Manual (OECD, 2005) and Bessant and Tidd (2007), innovation is characterized as a kind of change that introduces new organizational practices and falls into four categories: (1) innovation of products and/or services; (2) process innovation; (3) management (organizational) innovation and (4) marketing innovation (competitive position).

In practice innovation of products or services, usually occur together, product innovations often lead to innovations in their production process and vice versa; however, this synergy does not always occur, both can also be interdependent, which adds complexity to the relationship innovation performance (Tidd, Bessant \& Pavitt, 1997; Tidd, 2001).

Prajogo (2016) points out that the categorization of the dimensions of innovation (product or process) is important because it is related to the strategy that a company adopts to meet the

Product and sustainable innovation 
REGE 27,4

demand and market opportunities, capitalizing on the ability and organizational skills and impacting company' performance. Product innovation can improve sales because it has better performance and reliability or durability, better features such as integrated facilities or aesthetics compared to existing products offered by competitors in the market, thus an important aspect of competitive advantage of innovation product is that customers can clearly perceive the values, which can lead them to the purchase decision (Prajogo, 2016; Xin, Yeung \& Cheng, 2010).

Coherently, product (Sarpong \& Maclean, 2012; Zhang, Qi, Wang, Zhao \& Pawar, 2019) and process innovations (Linder \& Sperber, 2019) have a direct impact on the organization. According to Zhang, Qi, Wang, Zhao and Pawar (2019), business and political ties improve the performance of product innovation, as well as the influences of cultural and institutional environments, provide insights on how to use business and the political ties of managers to product innovation in China and India. However, Sarpong and Maclean (2012) demonstrate that vision incongruence on the part of different stakeholders regarding the future innovation may impede the generation of a shared interpretation of the future, and hence the subsequent capture of value.

According to Najafi-Tavani, Najafi-Tavani, Naudé, Oghazi and Zeynaloo (2018), in the presence of absorptive capacity, only collaboration with research organizations and competitors have a positive effect on product innovation capability. In the case of process innovation capability, collaboration with research organizations and suppliers are the most important factors.

In a meta-analysis Rousseau, Mathias, Madden and Crook (2016) reviewed 62 studies over 20 years and confirmed a strong link between innovation and performance, showing various contingencies: (1) the inconsistency between the performance results is motivated in part by the appropriation of part of the value generated by innovation, by the stakeholders and (2) the hyper competition is persistent over time and across all industries, there is evidence that the integration of product and process innovation generates stronger performance gains than the product innovation alone and that big companies get greater performance benefits from innovation when compared to small businesses.

Little is said about the negative attributes of innovation, as innovation in general has a positive connotation. By analyzing all the negative attributes that innovation can present, there are some trends regarding the negative aspects of innovations, which were scientific, technical and technological; these concerns are primarily related to health (accidents, toxicity, injury, radiation) and environmental concerns (deforestation and pollution) (Baskaran \& Mehta, 2016), also from an organizational perspective some negative outcomes may be considered such as employee dissatisfaction, increased costs and market risks (Simpson, Siguaw \& Enz, 2006). With the increased likelihood of ecological turbulence, caused by human actions we approach a global catastrophic threshold; sustainable innovations may be the transformation needed to safeguard our planet for the generations yet to come (Leach, Rockström, Raskin, Scoones, Stirling, Smith, Thompson, Millstone, Ely, Arond, Folke \& Olsson, 2012).

However, Reficco, Gutiérrez, Jaén and Auletta (2018) point out that a business model can be a border-spanning system that comprises several companies in which value is created, exchanged and captured, becoming collaborative mechanisms for sustainable innovation.

\subsection{Sustainable innovation}

Our planet has limited natural resources, and the constant misuse of these resources coupled with increasing economic activity (production and consumption) requires more inputs of energy and material, compromising its balance and the life of all beings that inhabit it (Panayotou, 2016; Elimam, 2017). According to Guisande, Rueda-Quecho, Rangel-Silva and Ríos-Vasquez (2018), environmental impact assessment studies are most frequently focused 
on assessing the possible impacts of a proposal and identifying alternatives, in order to minimize environmental damage. In this scenario, people, companies of different sizes and sectors, mineral and agro-industrial activities have negatively impacted the environment. For Houshyar, Chen and Chen (2019), agricultural production inevitably poses adverse impacts on local environment, while the collective action of farmers can also contribute positively to sustainable resources management.

However, according to Nidumolu, Prahalad and Rangaswami (2009), many companies are convinced that the more environment-friendly they become, the more the effort will erode their competitiveness; they believe it will add to costs and will not deliver immediate financial benefits. In this context, several research has highlighted that the use of environmental practices leads to the preservation of the environment and brings economic benefits to organizations (Gold, Seuring \& Beske, 2010; Cheng, Yang \& Sheu, 2014; Severo, de Guimarães \& Dorion, 2017b).

The growing awareness of environmental sustainability reached business reality. Consumers and businesses are looking for alternatives to mitigate urgent environmental demands resulting from the continued population and economic expansion so that in the future there may be a stability between consumption practices and environmental resource usage (Gold, Seuring \& Beske, 2010; De Medeiros, Ribeiro \& Cortimiglia, 2014; Severo, de Guimarães \& Dorion, 2017b; Marcon, De Medeiros \& Ribeiro, 2017).

Among these practices, Marcon, De Medeiros \& Ribeiro, 2017 discuss the best environmentally sustainable innovation practices developed and adopted by multinationals operating in Brazil. The authors emphasize that companies have developed product innovation practices, processes, organization and marketing in order to balance commercial and environmental interests with regard to sustainable growth; all the 33 multinationals companies analyzed have developed a wide range of actions; however, considering the practices observed, the researchers found that innovations related to processes appeared more often, followed by activities related to organizational innovation, product innovation and marketing innovation (Marcon, De Medeiros \& Ribeiro, 2017). González-Benito and González-Benito (2006) point out that the environmentally sustainable innovation activities can be analyzed through three perspectives: (1) organizational (changes in environmental company policies through modification procedure and allocation of environmental responsibilities); (2) Operating (changes in production and operation of products and processes) and (3) communication (disclosure to society of environmentally sustainable actions taken).

Much has been said about the management of environmental sustainability and its impact on companies' performance, as well as the possibility of being used as a competitive advantage (Shrivastava, 1995; Chen, Lai \& Wen, 2006; Chen, 2008; Gold, Seuring \& Beske, 2010; Cheng, Yang \& Sheu, 2014). Hart (1995) proposed his theory of competitive advantage based on the company's relationship with the natural environment, where he suggests that industrial society will evolve to the point where sustainable development will be the norm; then the technological, organizational and human resources that meet the environmental goals of a company should be considered even more valuable.

Even when not required to do so some companies are willing to invest in activities related to environmental sustainability, which could increase the productivity of their resources through innovations that consider environmental sustainability, but can also design and develop products that enable higher profits and better corporate image (Chen, Lai \& Wen, 2006; Franceschini, Faria \& Jurowetzki, 2016). Companies that implement a more proactive approach to managing their environmental performance are generally better able to reap the benefits of sustainability, for example, reducing energy consumption and raw materials that result in less waste/pollution or better performance from the market (Ramanathan, He, Black, Ghobadian \& Gallear, 2017).
Product and sustainable innovation 
REGE 27,4

As a company develops an environmental policy, it consequently develops an environmental reputation, since this reputation can be a source of market advantages, there is a link between the company's green innovation skills and sustainability image, and it must be built on a reputation for green innovation performance, and once it is achieved, it can become a valuable intangible resource (Chen, 2008). Coherently, companies can gain competitive advantage by managing ecological variables (Chen, Lai \& Wen, 2006). In this context, the employees' perspective on the company's environmental performance, where they work, may affect their willingness to work for the organization; companies with a poor environmental record will find it increasingly difficult to recruit and retain staff engaged in sustainable innovations; employee engagement can be seen as a critical strategy to identify and implement innovative sustainability approaches and initiatives (Veleva, Bodkin \& Todorova, 2017).

According to Gast, Gundolf and Cesinger (2017), there are some factors that can be considered precursors of the decision to conduct a business in an environmentally sustainable path, and they may be observed in a micro level, such as: (1) values and personal ideals (individuals who give equal consideration to social, economic and environmental); (2) Mean level that includes the market and industry (as a reaction to pressure from customers, suppliers, investors and competitors), prioritizing economic objectives over social or environmental and (3) macro-level result of external political pressures, legislation and its likely penalties.

Required by businesses, a holistic perception of innovations and analysis of their importance and actual impact on environmental sustainability, since companies cannot isolate themselves after all, the same influence habitat where they are inserted; the environmental management can provide a competitive opportunity and benefit the community where it is placed (González-Benito \& González-Benito, 2006; Van Den Heiligenberg, Heimeriks, Hekkert \& Van Oort, 2017). This view may reflect the increased awareness of stakeholders and consumers about the need for the implementation of meaningful innovations that improve environmentally sustainable consumption (Simpson, Siguaw \& Enz, 2006).

To address this pressing issue, the dissemination of technological and organizational innovation oriented to improve quality of life is necessary, nowadays it is a latent need to develop new and economic viable sustainable innovation, that must be undertaken in order to address both issues, social and environmental, also considering the current and future environmental needs (De Medeiros, Ribeiro \& Cortimiglia, 2014; Franceschini, Faria \& Jurowetzki, 2016). In recent decades, much has been achieved with respect to awareness of environmental issues, but there are still significant changes in the world so that businesses can be environmentally efficient, which would require finding a balance between socioeconomic needs and environmental issues, aiming at cleaner production and resource efficiency that end up reflecting on generating income and benefits for businesses and society as a whole (Khalili \& Duecker, 2013; Luken, Van Berkel, Leuenberger \& Schwager, 2016; Bolis, Morioka \& Sznelwar, 2017).

After the recent US output of the Paris Agreement, established in 2015 and starting and applied in 2020, the world takes up the discussion of the need for all countries of the world to commit to reducing emissions of greenhouse gases, from the 197 countries that originally signed the agreement 153 have ratified this decision (Unfccc, 2017). The Paris Agreement establishes that all nations should endeavor to combat climate change and adapt to its effects, with enhanced support to help developing countries to do so; to achieve these goals, a new framework will be implemented with new technology and an enhanced training, thus supporting the actions of developing and most vulnerable countries according to their own national objectives, also providing more action transparency (Nytimes, 2017). 


\section{Method}

This was a quantitative and descriptive study to analyze the relevance of sustainable innovation in products and services innovation, in companies in the northern region of Rio Grande do Sul (Brazil) (Figure 1), which according to Hair, Anderson, Tatham and Black (2007) brings benefits providing the possibility of measuring the variations in different ratios, so that there is a positive confirmation of the results. In this scenario, the quantitative research presents a multiple vision and statistics, due to complexity in the reviews and analysis of data presentations; it is that descriptive research needs to clearly present the results to the consistent detail of the related facts. According to Hair, Anderson, Tatham and Black (1988), quantitative data are measures that use numbers, represent the ownership of something, and they are often used in collecting company financial records, sales records and questionnaires. However, descriptive research is not easy to understand, it needs attention when determining the facts, to achieve a broad view of the issues.

For data collection, we used a survey through questionnaires. According to Hair, Anderson, Tatham and Black (2007), the survey seeks to analyze a great amount of knowledge, as well as bringing constructive opinions on the objective of the research, and a method that involves the application of a structured questionnaire where their goal is to get specific information of respondents. This technique is used in quantitative research where the objectives aim to raise the maximum number of respondents for the identification and definition of the causes of the problems (Hair, Anderson, Tatham \& Black, 2007). For this purpose, a search of the type Survey is assumed to be a universe of hundreds or thousands of elements (Malhotra, Rocha, Laudisio, Altheman, Borges \& Taylor, 2005). Thus, by a significant sample, the quantitative research instrument occurred through a descriptive Survey, through questionnaires. Regarding the number of times, the research was a cut-cross, since the collection occurred in a single moment, intending to analyze the state of the variables at any given time.

Responses were analyzed with a 5-point Likert scale which ranges from totally disagree to fully agree (1-totally disagree, 2-partially disagree, 3-neither agree nor disagree, 4-partially

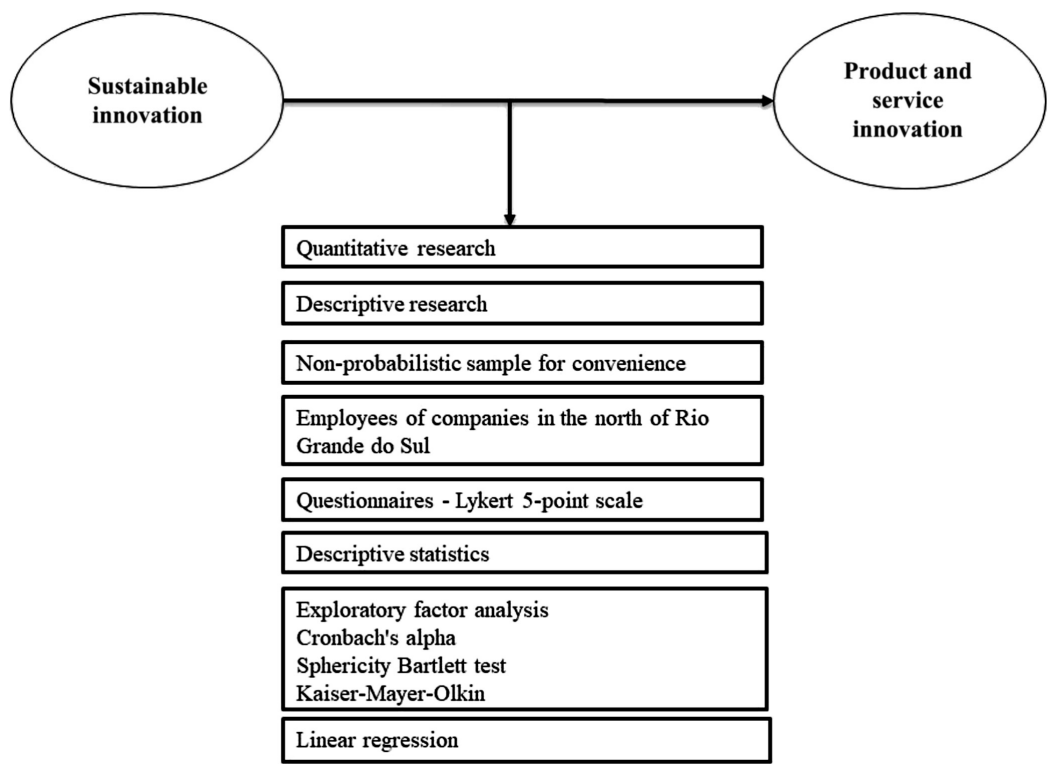

Product and sustainable innovation
Figure 1.

Conceptual model and research techniques 
REGE 27,4

\section{6}

agree and 5-fully agree). The questionnaire has four questions that characterize the respondent's profile and 11 questions relating to the constructs used (Table 1):

(1) Product innovation and service (PIS): adapted from the study of De Guimarães, Severo, Dorion, Coallier and Olea (2016) which analyzed the antecedent features of product innovation in the furniture industry in Southern Brazil; and the research by Severo, de Guimarães and Dorion (2017b), which measured the relationship between the constraints on sustainable product innovation and financial performance in 762 companies of different sizes, carried out in the leading metal-mechanic sector in Brazil.

(2) Sustainable innovation (SI): adapted from the study by Severo, de Guimarães and Dorion (2017b) and the study by Severo, Dorion and Guimarães (2017a), which analyzed the product and process environmental sustainability innovations that are developed by automotive metal-mechanic companies.

Therefore, the questionnaire was validated by two doctors who are experts in the subject area of studies being carried out, with a pretest with 18 respondents to check the understanding of the issues and the duration.

The questionnaires were applied online by Google Docs and conducted in person. The target population is the employees of the companies in the northern region of Rio Grande do Sul state (Brazil). The data were collected between June 1, 2017 and June 30, 2017. Coherently, the choice of respondents gave a nonprobabilistic way for convenience (Malhotra, 2012), where the selection of sample units is the responsibility of the researcher, in addition to all the existing sampling techniques, it takes less time and is considered the least expensive. Sample elements are accessible, cooperative and easy to measure.

\begin{tabular}{|c|c|c|c|}
\hline \multicolumn{2}{|c|}{ Observable variables } & $\begin{array}{l}\text { Factor } \\
\text { loadings }\end{array}$ & Commonality \\
\hline \multicolumn{4}{|c|}{ Construct product innovation and service (PIS) } \\
\hline & $\begin{array}{l}\text { Innovations improved the quality of goods or services offered by the } \\
\text { company }\end{array}$ & 0.817 & 0.668 \\
\hline PIS2 & $\begin{array}{l}\text { Innovations have expanded the range of goods or services offered by } \\
\text { the company }\end{array}$ & 0.873 & 0.769 \\
\hline PIS3 & $\begin{array}{l}\text { Innovations of product/service offered opened new markets for the } \\
\text { company }\end{array}$ & 0.800 & 0.652 \\
\hline PIS4 & $\begin{array}{l}\text { Innovations of product/service offered have reduced the impact on } \\
\text { the environment }\end{array}$ & 0.651 & 0.434 \\
\hline \multicolumn{4}{|c|}{ Note(s): Mean 4.166; standard deviation 0.641; Cronbach's alpha 0.747; KMO 0.765} \\
\hline \multicolumn{4}{|c|}{ Construct sustainable innovation (SI) } \\
\hline SI1 & Process innovations decreased water consumption & 0.833 & 0.711 \\
\hline & Process innovations decreased energy consumption & 0.867 & 0.783 \\
\hline & Process innovations decreased waste emission & 0.845 & 0.762 \\
\hline SI4 & $\begin{array}{l}\text { The company is premised on sustainability environmental } \\
\text { development of innovations }\end{array}$ & 0.649 & 0.457 \\
\hline SI5 & $\begin{array}{l}\text { The company uses environmental practices in innovation product/ } \\
\text { service and process }\end{array}$ & 0.744 & 0.554 \\
\hline SI6 & $\begin{array}{l}\text { The company has a specific department to deal with environmental } \\
\text { issues }\end{array}$ & 0.750 & 0.563 \\
\hline SI7 & The use of environmental practices caused a reduction of waste & 0.828 & 0.707 \\
\hline \multicolumn{4}{|c|}{ Note(s): Mean 3.117; Standard Deviation 0.868; Cronbach's alpha 0.903; KMO 0.790} \\
\hline
\end{tabular}

Note(s): Mean 3.117; Standard Deviation 0.868; Cronbach's alpha 0.903; KMO 0.790
Table 1.

Variables-varimax rotation 
As Hair, Anderson, Tatham and Black (2007), nonrandom sample is used when the response is not clearly defined by a sample calculation. There were a total of 120 responses, from which 13 questionnaires were excluded because they were considered outliers (with a large number of unanswered questions or only 1 point on the Likert scale); after this, the selected sample were 107 valid cases (respondents).

For the data analysis, we used descriptive statistics, also an exploratory factor analysis (EFA), which according to Hair, Anderson, Tatham and Black (2007) aimed to investigate the relationship between observable variables, gathering observable variables, correlated factors, in addition it is a statistic that measures the information of certain groups, defining patterns. In this sense, EFA presents a class of processes used for data summarization, as well as grouping information originally contained in a group of variables into a set of factors (Hair, Anderson, Tatham \& Black, 1998). Also according to Hair, Anderson, Tatham and Black (2007), the EFA is a study that verifies the variance and may perform the effects comparison. For that purpose, tests of normality, internal consistency and data reliability were also used (Cronbach's alpha; Bartlett's test for sphericity; Kaiser-Mayer-Olkin (KMO)).

In this scenario, to see the importance of in product and service innovation, we used the linear regression. According to Hair, Anderson, Tatham and Black (2007), the linear regression analyses the relationship between the study variables and is considered an appropriate method when the research problem involves a single dependent variable, which can be related to two or more independent variables. Pestana and Gageiro (2003) point out that linear regression is a statistical, descriptive and inferential technique that allows the analysis of the relationship between a dependent variable $(Y)$ and a set of independent variables ( $X^{\prime}$ s).

According to Maddala (1992), to verify the accuracy of the regression model, we use the coefficient of determination $\left(R^{2}\right)$, defined as the proportion of the variance of the dependent variable that is explained by the independent variables. The value of this coefficient can vary between 0 and 1 and the closer to 1 , the greater the explanatory power of the regression model.

For the formation of a database, the information obtained in the quantitative research were grouped and revised and the data, statistically treated, to ascertain the relationship of to product and process innovation. For this purpose, in the linear regression analysis, we used the SPSS 230.0 software for Windows ${ }^{\circledR}$.

\subsection{Sample profile}

The sample consisted of 107 respondents, employees in companies in the northern region of the state of Rio Grande do Sul (Brazil); of all the respondents, 70\% were female. Regarding family income, $47 \%$ of respondents had an average monthly income of 2 to 4 minimum wages and $39 \%$ of them had 4 to 10 minimum wages. Regarding the age of respondents, $79 \%$ of them were aged between 25 and 35 years. Regarding the size of the company, $63 \%$ of them work in mediumsized organizations, meaning an annual revenues exceeding Brazilian real (BRL) $3.6 \mathrm{~m}$ and equal to or less than BRL $300 m$ (US $\$ 1,146,460.31$ and US $\% 95,538,358,65$ - the BRL with values converted to US dollars, equivalent to BRL 3,1401 BRL to one US dollar, as of July 21, 2017).

\section{Results and discussion}

\subsection{Exploratory factor analysis}

The first part of the analysis was to rotate the EFA using the following parameters: (1) use of 11 variables (Table 1); (2) extraction applied the principal component analysis, based on eigenvalue; (3) varimax rotation and (4) display all the coefficients, to get an overview of the indicators in which Hair, Anderson, Tatham and Black (2007) note that the coefficients below 0.4 are not significant and therefore, should be eliminated, resulting in latent variables called constructs. In cluster analysis of variables, the observable EFA were grouped into two constructs (factors): (1) PISs; and (2) SI.
Product and sustainable innovation 
REGE 27,4

\section{8}

Table 1 shows the result of principal component analysis, showing the mean, standard deviation, observable variables (questions) and their respective factor loadings. In order to verify the reliability of simple observable variables we calculated the Cronbach's alpha, which should be above 0.7 (Lee \& Hooley, 2005; Hair, Anderson, Tatham \& Black, 2007). Depending on this, the results showed values for Cronbach's alpha higher than 0.7 for the two constructs (Table 1) and comprising 0.837 to calculate the data together.

Regarding the data preparation, we performed the Bartlett's test for sphericity $(\phi<0.05)$ and to evaluate the homogeneity of variances and measured the KMO index, which should be above 0.5 (Pestana and Gageiro, 2003). To test the homogeneity of variances Bartlett's sphericity test was performed, the results were significant $(p<0.05)$ for both the constructs, as well as the data set, the KMO index, value was 0.765 for the data set, showing the normality of the data. Regarding the factor loadings (Table 1), we found that they are above 0.4 , which according to Hair, Anderson, Tatham and Black (2007) is considered as acceptable, representing no need to exclude any of the observable variables.

In the construct PIS, the question with the highest factor loading (0.873) was the PIS2 "Innovations have expanded the range of goods or services offered by the company", which corroborates the previous research by Tidd (2001) and Prajogo (2016), since innovations enable changes through the development or use of new components, features and technologies for the production of new products and the improvement of production processes technologies necessary to produce goods and services. Also noteworthy is the PIS1, value of 0.817 , the assertion "Innovations improved the quality of goods or services offered by the company", which is in line with research by Prajogo (2016) and Xin, Yeung and Cheng (2010), since organizations seek to respond to the market's demand and needs, impacting on organizational performance.

Concerning the construct SI, the question with the highest factor loading (0.867) was the SI2 "Process innovations decreased energy consumption", which corroborates the research by Elimam (2017) and Gold, Seuring and Beske (2010), since s demonstrate a growing awareness of environmental sustainability in the business world; consumers and businesses are looking for alternatives so that there is stability between consumption practices and the environment. Depending on this, we emphasize SI3 "Process innovations decreased waste emission" with factor loading of 0.845, which confirms the research Paulraj (2011) and Dowell and Muthulingam (2017), that is innovations enable the reduction of inputs used in production, moreover increasing reuse and recycling, while improving environmental and financial performance.

Therefore, we also carried out the verification of commonality, as analysis of the scale parameter, which values should be above 0.5 since it refers to the total amount of variance that an original variable shares with the other variables of the survey (Hair, Anderson, Tatham, \& Black, 2007). As can be seen in Table 1, PIS4 and SI4 the questions presented a low commonality, however, they were maintained in research, since they are essential to the understanding of the constructs, which according to Hair, Anderson, Tatham and Black (2007) stands as a criterion that can be used by the researchers.

After verifying the adjustment of the EFA for the statistical analysis of the survey data, the factors were identified through the principal component analysis method, which converts a set of variables into a new set of composite and linear variables, which are not correlated, for that the number of factors was not previously defined as scores (Hair, Anderson, Tatham \& Black, 2007). In this context, as highlighted in Table 2, we considered two factors (constructs), which explains $64.16 \%$ of the variability in the data.

\subsection{Multiple linear regression}

To check the importance of in product and service innovation we used the linear regression (Hair, Anderson, Tatham \& Black, 2007). The analysis consisted on multiple linear regression relationships between: (1) PIS and SI. The model generated with the PIS builds the mean as 
the dependent variable and the SI (SI1, SI2, SI3, SI4, IA5, SI6, SI7-Table 1) as independent variables. Coherently, the linear regression indicates the cumulative effects of a group of explanatory variables $(X 1, X 2, X 3$, etc.) in a dependent variable $(Y)$ and the separate effects of these explanatory variables $(Y=\beta 1 X 1+\beta 2 X 2+\beta 3 X 3+\ldots+\beta 0)$ (Hair, Anderson, Tatham \& Black, 2007).

Then we performed the Pearson's correlation coefficient, this analysis seeks to determine whether some independent variables are highly correlated and the fit through the data of two variables, and this may occur when the correlations are between or above 0.8 (Wooldrigge, 2006). In the data analyzed, the highest correlation is found between the variables SA4 $\leftrightarrow$ SA3 $(0,778)$, therefore, we did not observe the evidence of multicollinearity in the remaining questions.

As for the results found in the linear regression for the proposed model, it can be seen that the power of SI explanation in product/service innovation which is equivalent to $30.7 \%\left(R^{2}\right)$ (Table 3 ). The test showed the significance value of $<0.001$, indicating that the estimated regression model is suitable for the study.

With the result of the regression (Table 3), we noted that for these respondents, the SI is a determining factor of product and service innovation, which indicates an awareness of the respondents regarding environmental issues in companies in the northern region of the state of Rio Grande do Sul. These findings corroborate the studies by Panayotou (2016) and Marcon, De Medeiros and Ribeiro (2017), for issues involving environmentally practices covering processes, organization and marketing; they can balance commercial and environmental interests, providing gains for the company, the community and the environment.

\section{Conclusions}

The survey results show that SI has influence on innovations in products and services in the northern companies in the RS, as it showed a close relationship between SI $\leftrightarrow$ PIS, with a $R^{2}=0.307$, suggesting that organizations should invest in environmental actions, so that this is converted into innovative products and services. As discussed by Tidd (2001) and Prajogo (2016), punctuated innovations enable sustainable development processing or by use of novel components as well as the improvement of basic production processes technologies to produce a product. However, the study by Prajogo (2016) contributes to this research, since it emphasizes that the dimensions of product innovation are related to organizational strategy, which can positively impact the performance of the company.

It also appeared on the results, process innovations decreased energy consumption, and it is in line with the research by Gold, Seuring and Beske (2010), Elimam (2017) and Dowell and Muthulingam (2017), demonstrating that SI raises awareness toward environmental

\begin{tabular}{llcc}
\hline Components & Total & $\begin{array}{c}\text { Sums rotating shipments squared } \\
\text { \% of variance }\end{array}$ & Cumulative \% \\
\hline 1 & 4.41 & 40.094 & 40.094 \\
2 & 2.648 & 24.074 & 64.168
\end{tabular}

Table 2. Identified factors
Product and sustainable innovation

329

\begin{tabular}{ccccc}
\hline Model & $R$ & $R^{2}$ & Adjusted $R^{2}$ & Std. error of the estimate \\
\hline 1 & $0.554^{\mathrm{a}}$ & 0.307 & 0.258 & 0.552
\end{tabular}

Note(s): ${ }^{a}$ Predictors: (Constant) SI4, SI1, SI2, SI3, SI5, SI6, SI7; ${ }^{b}$ Dependent Variable: MEAN_PIS

Table 3 Model summary ${ }^{b}$ 
REGE 27,4 sustainability, causing consumers and companies to pursue alternatives to counterbalance consumption practices and the environment. In line with the results of this research, the study by Dowell and Muthulingam (2017) corroborates the research, noting that the implementation of energy-saving initiatives as well as environmental standards affects the implementation costs and adoption decisions of this environmental practice. In this scenario, the research by Gold, Seuring and Beske (2010) points out that sustainable management is a valuable interorganizational resource that can become a source of competitive advantage while providing economic, environmental and social performance on the full basis of a product's life cycle.

Another result of the survey shows that process innovations reduced the emission of waste, confirming the research by Paulraj (2011) and Dowell and Muthulingam (2017), emphasizing that innovations provide the reduction of inputs used in production, leading to improved financial outcome and environmental benefits. The research conducted by Paulral (2011) brings the important contribution of the significant role that internal resources/capabilities can play in the management of sustainable practices as well as organizational sustainability. Accordingly, companies should promote environmental guidance within their organization. To summarize practices, comprehensive processes can balance commercial and environmental interests, providing benefits to the company, the community and the environment.

It is emphasized that environmental issues must be linked to investments in environmental education projects in organizations, thus enabling a systemic and effective vision on this issue. The theoretical contributions are related to the scale to measure the behavior of individuals in relation to process/product/service innovation and sustainable environmental innovation. Thus, the measuring range has undergone a statistical analysis based on reliability parameters, normality and factor analysis, showing consistency in the concentration on observable factors as well, other organizations and scholars can use the constructs for future research.

The main managerial contribution of this research is to prove that the elements of (energy and water consumption, waste production and environmental practices) directly influence product/service innovations. Therefore, companies must use environmental precepts and practices in the development of innovation, to reduce production costs and environmental impact, since natural resources are finite and require a balanced and conscious consumption by organizations.

Regarding social contributions, the study points out that even in the case of medium-sized companies, located in the north of Rio Grande do Sul, where the economy is mainly based on agriculture (soy, wheat, rice and corn), employees perceive the importance of environmental innovation in the products and services offered. It is noteworthy that the ethnicity of the northern region is quite diverse, with descendants mainly of Italy and Germany, who began to emigrate to the country in the late 19th century. The population of the state of Rio Grande do Sul is largely made up of Portuguese, German, Italian, African, Lebanese and indigenous descendants, partly by Spaniards, Poles and French, among other immigrants, who contribute to regional development.

We recommend for future studies on the subject, to increase the number of respondents in an attempt to obtain more conclusive results. We also suggest the inclusion of other constructs, such as the organizational performance, in order to understand how competitive strategies are generated in the organizational environment and the impact on companies' earnings. We also suggest new research comparing regions, sectors and production chains to compare the performance of in product/service, marketing and organizational innovation. Based on the results of this research, new research questions arise such as: in addition to the environmental dimension, what is the influence of social factors on product/service innovations? Moreover, how do companies encourage workers to innovate using socioenvironmental precepts? 


\section{References}

Baskaran, S., \& Mehta, K. (2016), What is innovation anyway? Youth perspectives from resourceconstrained environments. Technovation, 52, 1-14.

Bessant. J., \& Tidd, J. (2007), Innovation and entrepreneurship. Chichester: West Sussex, England: John Wiley \& Sons.

Bolis, I., Morioka, S.N., \& Sznelwar, L.I. (2017), Are we making decisions in a sustainable way? The literature review about rationalities comprehensive for sustainable development. Journal of Cleaner Production, 145, 310-322.

Brito, E.P.Z., Brito, L.A.L., \& Morganti, F. (2009), Innovation and corporate performance: Profit or growth?. RAE eletrônica, 8(1), 1-25.

Calantone, R., Garcia, R., \& Dröge, C. (2003), The effects of environmental turbulence on new product development strategy planning. Journal of Product Innovation Management, 20(2), 90-103.

Chen, Y.S. (2008). The driver of green innovation and green image-green core competence. Journal of Business Ethics, 81(3), 531-543.

Cheng, C.C., Yang, C.L., \& Sheu, C. (2014), The link between eco-innovation and business performance: A Taiwanese industry context. Journal of Cleaner Production, 64, 81-90.

Chen, Y.S., Lai, S.B., \& Wen, C.T. (2006), The influence of green innovation performance on corporate advantage in Taiwan. Journal of Business Ethics, 67(4), 331-339.

Damanpour, F. (1991), Organizational innovation: A meta-analysis of effects of determinants and moderators. Academy of Management Journal, 34(3), 555-590.

De Guimarães, J.C.F., Severo, E.A., Dorion, E.C.H., Coallier, F., \& Olea, P.M. (2016), The use of organisational resources for product innovation and organisational performance: A survey of the Brazilian furniture industry. International Journal of Production Economics, 180, 135-147.

De Medeiros, J.F., Ribeiro, J.L.D., \& Cortimiglia, M.N. (2014), Success factors for environmentally sustainable product innovation: A systematic literature review. Journal of Cleaner Production, $65,76-86$

Dosi, G. (1990), Finance, innovation and industrial change. Journal of Economic Behavior \& Organization, 13(3), 299-319.

Dowell, G.W., \& Muthulingam, S. (2017), Will firms go green if it pays? The impact of disruption, cost, and external factors on the adoption of environmental initiatives. Strategic Management Journal, 38(6), 1287-1304.

Elimam, H. (2017), How green economy contributes in decreasing the environment pollution and misuse of the limited resources?. Environment and Pollution, 6(1), 10-18.

Franceschini, S., Faria, L.G., \& Jurowetzki, R. (2016), Unveiling scientific communities about sustainability and innovation. A bibliometric journey around sustainable terms. Journal of Cleaner Production, 127, 72-83.

Garcia, R., \& Calantone, R. (2002), A critical look at technological innovation typology and innovativeness terminology: A literature review. Journal of Product Innovation Management, 19(2), 110-132.

Gast, J., Gundolf, K., \& Cesinger, B. (2017), Doing business in a green way: A systematic review of the literature entrepreneurship ecological sustainability and future research directions. Journal of Cleaner Production, 147, 44-56.

Gold, S., Seuring, S., \& Beske, P. (2010), Sustainable supply chain management and interorganizational resources: A literature review. Corporate Social Responsibility and Environmental Management, 1(4), 230-245.

González-Benito, J., \& González-Benito, Ó. (2006), A review of determinant factors of environmental proactivity. Business Strategy and the Environment, 15(2), 87-102.

Gopalakrishnan, S. (2000), Unraveling the links between dimensions of innovation and organizational performance. The Journal of High Technology Management Research, 11(1), 137-153.

Product and sustainable innovation 
REGE 27,4

Guisande, C., Rueda-Quecho, A.J., Rangel-Silva, F.A., \& Ríos-Vasquez, J.M. (2018), Eia: An algorithm for the statistical evaluation of an environmental impact assessment. Ecological Indicators, 93, 1081-1088.

Hair, J.F. Jr., Anderson, R.E., Tatham, R.L., \& Black, W.C. (1998), Multivariate data analysis with readings. 5th.ed, New Jersey: Prentice Hall.

Hair, J.F. Jr., Black, W.C., Bardin, B.J., \& Anderson, R.E. (2007), Multivariate date analysis. 7th ed., New Jersey: Prentice Hall.

Hansen, E.G., Grosse-Dunker, F., \& Reichwald, R. (2009), Sustainability innovation cube - a framework to evaluate sustainability-oriented innovations. International Journal of Innovation Management, 13(4), 683-713.

Hart, S.L. (1995), A natural-resource-based view of the firm. Academy of Management Review, 20(4), 986-1014.

Houshyar, E., Chen, B., \& Chen, G.Q. (2019), Environmental impacts of rice production analyzed via social capital development: An Iranian case study with a life cycle assessment/data envelopment analysis approach. Ecological Indicators, 105, 675-687.

Khalili, N.R., \& Duecker, S. (2013), Application of multi-criteria decision analysis in design of sustainable environmental management system framework. Journal of Cleaner Production, 47, 188-198.

Leach, M., Rockström, J., Raskin, P., Scoones, I., Stirling, A., Smith, A., Thompson, J., Millstone, E., Ely, A., Arond, E., Folke, C., \& Olsson, P. (2012), Transforming innovation for sustainability. Ecology and Society, 17(2), 11.

Lee, N., \& Hooley, G. (2005), The evolution of 'classical mythology' within marketing measure development. European Journal of Marketing, 39(3/4), 365-385.

Linder, C., \& Sperber, S. (2019), Towards a deeper understanding of the emergence of process innovations: Which role do inter-organisational learning and internal knowledge exploitation play?. Journal of Engineering and Technology Management, 53, 33-48.

Liu, Y., Zhu, Q., \& Seuring, S. (2017), Linking capabilities to green operations strategies: The moderating role of corporate environmental proactivity. International Journal of Production Economics, 187, 182-195.

Luken, R.A., Van Berkel, R., Leuenberger, H., \& Schwager, P. (2016), A 20-year retrospective of the national cleaner production centres programme. Journal of Cleaner Production, 112, 1165-1174.

Maddala, G.S. (1992), Introduction to econometrics. 2nd ed., Englewood Cliffs: Prentice Hall.

Malhotra, N.K. (2012), Pesquisa de marketing: uma orientação aplicada. 6th ed., Porto Alegre: Bookman Editora.

Malhotra, N.K., Rocha, I., Laudisio, M.C., Altheman, É., Borges, F.M., \& Taylor, R.B. (2005), Introdução à pesquisa de marketing. 1st ed., São Paulo: Prentice Hall.

Marcon, A., De Medeiros, J.F., \& Ribeiro, J.L.D. (2017), Innovation and environmentally sustainable economy: Identifying the best practices developed by multinationals in Brazil. Journal of Cleaner Production, 160, 83-97.

Najafi-Tavani, S., Najafi-Tavani, Z., Naudé, P., Oghazi, P., \& Zeynaloo, E. (2018), How collaborative innovation networks affect new product performance: Product innovation capability, process innovation capability, and absorptive capacity. Industrial Marketing Management, 73, 193-205.

Nidumolu, R., Prahalad, C.K., \& Rangaswami, M.R. (2009), Why sustainability is now the key driver of innovation. Harvard Business Review, (Sep), 57-64.

NyTimes (2017), available at: https:/www.nytimes.com/2017/06/01/world/europe/climate-parisagreement-trump-china.html/ (accessed 08 July 2017).

OECD (2005), The measurement of scientific and technological activities - proposed guidelines for collecting and interpreting technological innovation data. Oslo manual, 3rd ed., Paris: OECD and Eurostat. 
Panayotou, T. (2016), Economic growth and the environment. in N. Haenn, R.R. Wilk \& A. Harnish (Eds.), The Environment in Anthropology: A Reader in Ecology, Culture and Sustainable Living, (2nd ed., pp. 140-148), New York University Press, New York, NY.

Paulraj, A. (2011), Understanding the relationships between internal resources and capabilities, sustainable supply management and organizational sustainability. Journal of Supply Chain Management, 47(1), 19-37.

Pestana, M.H., \& Gageiro, J.N. (2003), Análise de dados para ciências sociais: A complementaridade do SPSS. Lisboa: Edições Sílabo.

Prajogo, D.I. (2016), The strategic fit between innovation and business strategies in delivering business environment performance. International Journal of Production Economics, 171(2), 241-249.

Ramanathan, R., He, Q., Black, A., Ghobadian, A., \& Gallear, D. (2017), Environmental regulations, innovation and firm performance: A revisit of the porter hypothesis. Journal of Cleaner Production, 155, 79-92.

Reficco, E., Gutiérrez, R., Jaén, M.H., \& Auletta, N. (2018), Collaboration mechanisms for sustainable innovation. Journal of Cleaner Production, 203, 1170-1186.

Rousseau, M.B., Mathias, B.D., Madden, L.T., \& Crook, T.R. (2016), Innovation, firm performance, and appropriation: A meta-analysis. International Journal of Innovation Management, 20(3), 1650033.

Sarpong, D., \& Maclean, M. (2012), Mobilising differential visions for new product innovation. Technovation, 32(12), 694-702.

Schumpeter, J.A. (1934), The theory of economic development: An inquiry into profits, capital, credit, interest, and the business cycle. Cambridge: Transaction Publishers.

Severo, E.A., de Guimarães, J.C.F., \& Dorion, E.C.H. (2017b), Cleaner production and environmental management as sustainable product innovation antecedents: A survey in Brazilian industries. Journal of Cleaner Production, 142, 87-97.

Severo, E.A., Dorion, E.C.H., \& Guimarães, J.C.F.D. (2017a), Innovation and environmental sustainability: Analysis in Brazilian metal-mechanic industry. International Journal of Innovation and Sustainable Development, 11(2-3), 230-248.

Shrivastava, P. (1995), Environmental technologies and competitive advantage. Strategic Management Journal, 16(1), 183-200.

Simpson, P.M., Siguaw, J.A., \& Enz, C.A. (2006), Innovation orientation outcomes: The good and the bad. Journal of Business Research, 59(10), 1133-1141.

Tidd, J., Bessant, J.R., \& Pavitt, K. (1997), Managing innovation: Integrating technological, market and organizational change. Chichester: Wiley.

Tidd, J. (2006), A review of innovation models. London: Imperial College London, 16.

Tidd, J. (2001), Innovation management in context: Environment, organization and performance. International Journal of Management Reviews, 3(3), 169-183.

Unfccc (2017), United nations framework convention on climate change. available at: https://www. unfccc.int/ (accessed 08 July 2017).

Van Den Heiligenberg, H.A., Heimeriks, G.J., Hekkert, M.P., \& Van Oort, F.G. (2017), A habitat for sustainability experiments: Success factors for innovations in their local and regional contexts. Journal of Cleaner Production, 169, 204-215.

Veleva, V., Bodkin, G., \& Todorova, S. (2017), The need for better measurement and employee engagement to advance a circular economy: Lessons from Biogen's 'zero waste' journey. Journal of Cleaner Production, 154, 517-529.

Vincent, L.H., Bharadwaj, S.G., \& Challagalla, G.N. (2004), Does innovation mediate firm performance?: A meta-analysis of determinants and consequences of organizational innovation. Georgia: Georgia Institute of Technology. 
REGE 27,4

\section{4}

Wooldrigge, J.M. (2006), Introduction to econometrics: A modern approach. São Paulo: Pioneer Thompson Learning.

Xin, J.Y., Yeung, A.C.L., \& Cheng, T.E.C. (2010), First to market: Is technological innovation in new product development in health care industries profitable?. International Journal of production Economics, 127(1), 129-135.

Zhang, M., Qi, Y., Wang, Z., Zhao, X., \& Pawar, K.S. (2019), Effects of business and political ties on product innovation performance: Evidence from China and India. Technovation, 80, 30-39.

\section{About the authors}

Dr Eliana Andréa Severo holds a Postdoctoral degree from the University of Caxias do Sul (UCS), Doctorate degree in Business Administration at the Pontifícia University Católica of Rio Grande do Sul (PUC-RS) and University of Caxias do Sul (UCS), Brazil. She has experience in the area of Business Administration, with emphasis in environmental management, innovation and entrepreneurship. She is currently Professor at the University Center UniFBV, Department of Professional Master in Business Management. Eliana Andréa Severo is the corresponding author and can be contacted at: elianasevero2@hotmail.com

Marcia Marisa Santanna Perin holds Master's Degree in Business Administration from the Faculdade Meridional (IMED) in Passo Fundo. She has experience in the area of Business Administration. She is currently Professor at the Faculdade Meridional (IMED), Postgraduate Program in Administration.

Dr Julio Cesar Ferro De Guimarães holds a Postdoctoral degree from the University of Caxias do Sul (UCS), Doctor in Business Administration at the Pontificia University Católica of Rio Grande do Sul (PUC-RS) and University of Caxias do Sul (UCS), Brazil. He has experience in the area of Business Administration, Emphasis in Management of Innovation, Business Competitiveness and Cleaner Production. He is a Professor at the Federal University of Pernambuco (UFPE), Graduate Program in Business Administration, Center for Applied Social Sciences (CCSA).

Elaine Taufer holds Master's Degree in Business Administration from the Faculdade Meridional (IMED) in Passo Fundo. She has experience in the area of Business Administration and she is a Professor at the Faculdade Meridional (IMED), Postgraduate Program in Administration.

Associate Editor: Felipe Lara

For instructions on how to order reprints of this article, please visit our website:

www.emeraldgrouppublishing.com/licensing/reprints.htm

Or contact us for further details: permissions@emeraldinsight.com 